\title{
Responsabilidade do Banco Central do Brasil pelos danos ocorridos aos clientes de instituições financeiras em liquidação extrajudicial ou falência
}

\author{
Rafael Ribeiro Calegari Gomes
}

\begin{abstract}
Resumo
Verifica a possibilidade de se responsabilizar o Banco Central do Brasil pelos danos ocorridos aos clientes de instituições financeiras em liquidação extrajudicial ou falência, constatada omissão no seu dever de fiscalização, aplicando a teoria subjetiva, baseada na culpa ou dolo. Aborda a intervenção estatal no domínio econômico, especialmente a atividade reguladora e a função fiscalizadora; o Sistema Financeiro Nacional e as instituições que o compõe; o papel do Banco Central do Brasil como órgão supervisor, responsável pela decretação de regimes especiais; além da responsabilidade estatal. Conclui ser possível a responsabilização do Poder Público pela violação do direito de crédito dos credores, desde que comprovados culpa e/ou dolo, resultando a omissão do ente público em condição que permite a ocorrência do evento lesivo.
\end{abstract}

Palavras Chave: Intervenção estatal no domínio econômico; Sistema Financeiro Nacional; instituições financeiras; Banco Central do Brasil; liquidação extrajudicial e falência; responsabilidade estatal.

\section{Introdução}

A intervenção estatal no domínio econômico deve ser utilizada como forma de atender ao interesse público.

No que se refere ao Sistema Financeiro Nacional, a atividade reguladora normativa e a função de fiscalização exercidas pelos órgãos competentes visam um mercado sólido, capaz de atrair investimentos, promover a realocação de capitais, controlar o câmbio e as taxas de juros, enfim, gerar crescimento econômico, intrinsecamente relacionado ao desenvolvimento social no sistema capitalista.

Extremamente importante nesse aspecto a supervisão exercida pelo Banco Central do Brasil, responsável pela decretação de regimes especiais para instituições financeiras que coloquem em risco a higidez do mercado e a condição patrimonial de seus clientes, o que faz com base na atividade reguladora e principalmente através das informações obtidas por meio da função fiscalizadora. 
Função esta que deve operar de forma eficaz, detectando os problemas existentes para que se possa atuar prontamente, sob pena de se incorrer em omissão, possibilitando a ocorrência de danos em larga escala.

Diante da infração a dever legal, embora existentes inúmeros poderes para se evitar a superveniência de acontecimentos danosos, surge a questão da responsabilização.

Eis o ponto crucial do presente trabalho, verificar a possibilidade de se responsabilizar o ente público incumbido da função de fiscalização que se revelou ineficiente ou mesmo inoperante, in casu, responsabilização do Banco Central do Brasil quando de liquidação extrajudicial ou falência de instituição financeira que sujeite seus clientes a danos, ou seja, a proteção pela violação da esfera juridicamente protegida de outrem.

\section{As funções do Banco Central do Brasil perante o sistema financeiro nacional como forma típica de intervenção estatal no domínio econômico}

A intervenção estatal no domínio econômico é característica marcante do Estado Social, resultado de uma transformação estrutural pela qual passou o Estado Liberal, devendo ser utilizada como forma de atender ao interesse público ${ }^{1}$.

No que se refere ao Sistema Financeiro Nacional, importante a supervisão exercida pelo Banco Central do Brasil (BACEN), responsável pela decretação de regimes especiais para instituições financeiras que coloquem em risco a higidez do mercado e a condição patrimonial de seus clientes, o que faz com base na atividade reguladora e através das informações obtidas por meio da função de fiscalização, a qual, diga-se desde já, deve operar de forma eficaz, detectando os problemas existentes para que se possa atuar prontamente, sob pena de se incorrer em omissão, possibilitando a ocorrência de danos em larga escala.

Trata-se de forma típica de intervenção no seio da vida econômica, manifestação do poder de polícia, isto é, mediante um conjunto de medidas normativas, que compreendem desde autorizações para funcionamento até regras que devem ser observadas obrigatoriamente para o regular desenvolvimento de determinada atividade, o Estado, por si mesmo ou por meio de pessoas que cria para determinada finalidade, atua como agente

1 BONAVIDES, Paulo. Do Estado Liberal ao Estado Social. 7. ed. São Paulo: Malheiros, 2004. 
normativo e regulador da atividade econômica, exercendo a função de fiscalização, que tem como pressuposto esse poder de regulamentação ao qual está estritamente relacionada na medida em que sua missão é verificar o cumprimento das exigências normativas.

O Sistema Financeiro Nacional é composto por várias instituições financeiras públicas e privadas, apresentando como órgão máximo de regulação e fixação de políticas monetária e creditícia o Conselho Monetário Nacional (CMN).

Está regulado pela Lei da Reforma Bancária, Lei no 4.595, de 31 de dezembro de $1964^{2}$, que vigora com status de lei complementar pelo princípio da recepção, dada a exigência do artigo 192 do texto constitucional.

O artigo 17 da referida lei define as instituições financeiras como sendo pessoas jurídicas públicas ou privadas que têm como atividade principal ou acessória: a) coleta, a intermediação ou a aplicação de recursos financeiros próprios ou de terceiros, em moeda nacional ou estrangeira; b) custódia de valores de propriedade de terceiros.

Pode-se afirmar que são caracterizados como instituições financeiras, de acordo com Luiz Tzirulnik ${ }^{3}$, os bancos oficiais ou privados; as sociedades de crédito, financiamento e investimentos; as cooperativas de crédito; as caixas econômicas e federais; as companhias de seguro e capitalização; as bolsas de valores; as sociedades corretoras de câmbio; as sociedades que promovam a distribuição de prêmios em imóveis, mercadorias ou dinheiro, mediante sorteio de títulos de sua própria emissão ou por qualquer outra forma; as pessoas físicas ou jurídicas que exerçam, por conta própria ou de terceiros, atividades relacionadas com a compra e venda de ações e quaisquer outros títulos, realizando, no mercado de capitais ou no mercado financeiro, operações ou serviços da mesma natureza daqueles efetuados pelas instituições financeiras; as pessoas físicas que exerçam quaisquer das atividades citadas de forma permanente ou eventual.

Instituições financeiras que têm como característica marcante a proibição da impetração de concordata (instituto atualmente extinto por força da nova lei de falências), como prescreve o artigo 45 da citada lei da Reforma Bancária, pelo que, ganham destaque

2 BRASIL. Lei no 4.595, de 31 de dezembro de 1964. Dispõe sobre a Política e as Instituições Monetárias, Bancárias e Creditícias, cria o Conselho Monetário Nacional, e dá outras providências. Diário Oficial, Brasília, DF, p. 012081, 31 dez. 1964.

3 TZIRULNIK, Luiz. Intervenção e Liquidação Extrajudicial das Instituições Financeiras. 2. ed. São Paulo: RT, 2000. p. 39. 
os regimes especiais a que estão sujeitas, adiante mencionados, não descartada a hipótese da decretação de falência.

Ao BACEN, órgão regulador/normativo e fiscalizador atuante sobre o Sistema Financeiro Nacional, compete cumprir e fazer cumprir as disposições que lhe são legalmente atribuídas pela legislação e as normas expedidas pelo CMN.

Administrativamente, o BACEN é uma autarquia federal vinculada ao Ministério da Fazenda. No mercado financeiro exerce primordialmente a supervisão, buscando um sistema financeiro sólido, que garanta a indispensável intermediação entre os agentes financeiros, garantido aos que investem uma adequada remuneração de seus recursos, e aos captadores de investimentos os recursos necessários às atividades que geram emprego, desenvolvimento social e econômico.

Bem por isso o inciso IX do artigo 10 e o inciso VII do artigo 11, todos da Lei $\mathrm{n}$ o 4.595, de 31 de dezembro de 1964, atribuem-lhe competência para, respectivamente, exercer a fiscalização das instituições financeiras e aplicar as penalidades previstas; exercer permanente vigilância nos mercados financeiros e de capitais sobre empresas que, direta, ou indiretamente, interfiram nesses mercados e em relação às modalidades ou processos operacionais que utilizem.

As atribuições do BACEN também se estendem ao mercado de capitais, consoante estatui a Lei $\mathrm{n}$ - 4.728, de 14 de julho de $1965^{4}$, incisos II e III do artigo 2 ㅇ․

As funções exercidas pelo BACEN são típicas de intervenção estatal na atividade econômica, com vistas a garantir um sistema sólido, capaz de atrair investimentos, principalmente frente à internacionalização dos mercados financeiros, intimamente relacionada com o fenômeno da globalização, além da credibilidade necessária junto ao mercado financeiro interno.

Sistemas bancários instáveis e insolventes trazem sérias repercussões negativas para a economia e a política de um país, e conseqüentemente para seu governo, haja vista que, as instituições financeiras intermediam a moeda e o crédito no sistema econômico, onde se formam as taxas de juros. 4 BRASIL. Lei no 4.728, de 14 de julho de 1965. Disciplina o Mercado de Capitais e estabelece medidas para o
seu desenvolvimento. Diário Oficial, Brasília, DF, p. 006697, 16 jul. 1965. 
Procura-se por meio dessa intervenção recuperar ou mesmo eliminar do mercado instituições deficientes que possam vir a retirar a credibilidade de todo o sistema, ocasionando, entre outras conseqüências prejudiciais, as denominadas "corridas bancárias", capazes de gerar prejuízos em larga escala diante da diversidade e amplitude dos investimentos realizados pelas instituições financeiras, que poderiam vir à bancarrota com tal situação.

Outros objetivos visados são os de evitar fraudes e especulação de intermediários financeiros, proteger a poupança popular, bem como evitar o surgimento de monopólios.

Para isso o BACEN conta com um vasto arsenal normativo, instituindo controles técnicos e jurídicos para o regular funcionamento das instituições financeiras, emitindo comandos de caráter vinculante sobre operações, serviços, gestão e relação com o mercado.

Nesse sentido a Resolução no 2.099, de 17 de agosto de $1994^{5}$, aprovada pelo CMN, seguindo as exigências de adaptação aos princípios básicos para uma supervisão bancária eficaz elaborados pelos Acordos da Basiléia/Suíça, oriundos da criação em 1974 do Comitê de Supervisão Bancária da Basiléia, formado pelos representantes dos bancos centrais e órgãos de supervisão bancária dos países do Grupo dos Dez (G-10), que inclui Alemanha, Bélgica, Canadá, Estados Unidos, França, Holanda, Inglaterra, Itália, Japão e Suíça, além de Luxemburgo.

O anexo I trata da autorização para instalação, sendo indispensável, em síntese, que os controladores demonstrem capacidade técnica, idoneidade e capacidade financeira. 0 anexo II estabelece limites de capital realizado e patrimônio líquido para as instituições financeiras, inclusive para a sua instalação. O anexo III disciplina a instalação e o funcionamento de dependências de instituições autorizadas a funcionar pelo BACEN em território brasileiro. Já o anexo IV obriga as instituições financeiras a manterem um patrimônio líquido ajustado compatível com o grau de risco de suas estruturas de ativos, acompanhando esse anexo uma tabela onde figuram todos os ativos que as instituições podem possuir associados a diferentes fatores de ponderações de riscos.

5 BRASIL. Resolução no 2.099, de 17 de agosto de 1994. Aprova regulamentos que dispõem sobre as condições relativamente ao acesso ao Sistema Financeiro Nacional, aos valores mínimos de capital e patrimônio líquido ajustado, a instalação de dependências e a obrigatoriedade da manutenção de patrimônio líquido ajustado em valor compatível com o grau de risco das operações ativas das instituições financeiras e demais instituições autorizadas a funcionar pelo Banco Central. Disponível em: <http://www5.bcb.gov.br/>. Acesso em: 30 jun. 2004. 
A Lei no 9.447, de 14 de março de $1997^{6}$, foi responsável pela introdução de alterações legislativas importantes, em especial com relação aos poderes atribuídos ao BACEN para atuar no fortalecimento e no saneamento do mercado, com o objetivo de prevenir e solucionar crises de liquidez ou solvência de instituições financeiras.

Essa lei ampliou os poderes do BACEN nos regimes especiais, de que adiante se trata, de forma que, os interventores na intervenção, os liquidantes nas liquidações extrajudiciais e os conselhos diretores em regime de administração especial temporária, desde que autorizados pelo BACEN, passaram a poder transferir bens, direitos e obrigações, alienar ou ceder bens e direitos e acordar a assunção de obrigações, assim como proceder à constituição ou reorganização de sociedades, possibilitando, assim, a cisão entre a parte saudável e a insolvente.

A Resolução no 2.197, de 31 de agosto de $1995^{7}$, do CMN, que criou o Fundo Garantidor de Crédito ( $F G C)$, que é uma associação civil de direito privado, com prazo indeterminado de duração, cuja finalidade consiste na proteção dos depositantes e investidores de empresas bancárias até o limite individual por número de inscrição no Cadastro de Pessoas Físicas (CPF) no valor de R\$ 20.000,00 (vinte mil reais), nas hipóteses de sujeição aos regimes especiais de intervenção, de liquidação extrajudicial ou de falência.

São objeto da garantia proporcionada por esse fundo os seguintes valores: créditos provenientes de depósitos à vista ou sacáveis mediante aviso prévio; depósitos de poupança e depósitos a prazo, com ou sem emissão de certificado; letras de câmbio, letras imobiliárias e letras hipotecárias de emissão ou aceite de instituição bancária ou associação de poupança e empréstimo.

Ainda no contexto de regulação, agora estritamente prudencial/preventiva, a instituição da Central de Risco de Crédito por meio da Resolução no 2.390, de 22 de maio de

$6 \quad$ BRASIL. Lei no 9.447, de 14 de março de 1997. Dispõe sobre a responsabilidade solidária de controladores de instituições submetidas aos regimes de que tratam a Lei 6.024, de 13 de março de 1974, e o Decreto-lei 2.321, de 25 de fevereiro de 1987; sobre a indisponibilidade de seus bens; sobre a responsabilização das empresas de auditoria contábil ou dos auditores contábeis independentes; sobre privatização de instituições cujas ações sejam desapropriadas, na forma do Decreto-lei 2.321, de 1987, e dá outras providências. Diário Oficial, Brasília, DF, p. 005196, 15 mar. 1997.

7 BRASIL. Resolução no 2.197, de 31 de agosto de 1995. Autoriza a constituição de entidade privada, sem fins lucrativos, destinada a administrar mecanismo de proteção a titulares de créditos contra instituições financeiras.Disponível em: http;//www5.bcb.gov.br/. Acesso em: 30 jun. 2004. 
$1997^{8}$, do CMN, com a determinação que as instituições nela mencionadas prestem informações ao BACEN sobre o montante dos débitos de seus clientes, bem como de suas responsabilidades por garantia. A atual Central de Risco a partir do mês de julho de 2004 foi substituída pelo Sistema de Informações de Crédito (SCR), normatizado pela Resolução no 2.724, de 31 de maio de $2000^{9}$, do CMN, instrumento que vai permitir um acompanhamento mais detalhado do mercado de crédito.

O BACEN dentro de sua atividade reguladora/normativa e função de fiscalização possui ainda uma série de instrumentos de prevenção e solução ou amenização de crises, podendo-se destacar: a autorização para o funcionamento das instituições financeiras; autorização de quaisquer transferências de controle acionário, fusões, incorporações; exigência de condições para a posse e o exercício de cargos de administração; obrigatoriedade de aporte de capital mínimo; limites de alavancagem operacional; concessão de assistência financeira para crises de liquidez através da janela de redesconto (empréstimos mediante garantia); aumento de depósitos compulsórios; exigência de contabilidade uniformizada através do Plano de Contas das Instituições do Sistema Financeiro (COSIF - Circular no 1.273, de 29 de dezembro de $1987^{10}$ ); decretação de regimes especiais.

A função de fiscalização exercida de forma indireta e direta, acompanha a saúde financeira das instituições, tendo por objetivo certificar o cumprimento das regras ditadas pelos órgãos de supervisão, monitorando os riscos assumidos.

A fiscalização indireta é aquela exercida sem a presença física intensiva das equipes de fiscalização do BACEN, sendo realizado o acompanhamento com base nos dados contábeis mensalmente encaminhadas pelas instituições, possibilitando a obtenção de várias informações acessadas por meio do Sistema de Informações do Banco Central (SISBACEN).

8 BRASIL. Resolução no 2.390 de 22 de maio de 1997. Determina às instituições que especifica a prestação ao Banco Central do Brasil de informações sobre clientes, objetivando a implementação do sistema Central de Risco de Crédito. Disponível em: <http://www5.bcb.gov.br>. Acesso em: 30 jun. 2004.

9 BRASIL. Resolução no 2.724, de 31 de maio de 2000. Dispõe sobre a prestação de informações para o sistema Central de Risco de Credito. Disponível em: <http://www5.bcb.gov.br>. Acesso em: 30 jun. 2004.

10 BRASIL. Circular no 1.273, de 29 de dezembro de 1987. Institui o Plano Contábil Consolidado do Sistema Financeiro Nacional - COSIF. Disponível em: http://www5.bcb.gov.br/. Acesso em: 30 jun. 2004. 


\title{
Precisa a lição de Emílio Carlos Dantas $\operatorname{Costa}^{11}$ :
}

\begin{abstract}
As informações obtidas indiretamente alimentam um sistema chamado SUPER que interliga diversas bases de dados pertencentes ao SISBACEN e que pode ser acessado através de terminais de microcomputadores. Integrado ao SUPER está um programa chamado SENTINELA que, através de cálculos envolvendo as informações contábeis disponibilizadas, evidencia situações que possam representar risco para a instituição possibilitando a pronta atuação das equipes de fiscalização direta.
\end{abstract}

Ressalta-se ser possível a verificação de qualquer anormalidade que possa vir a criar riscos tanto para as instituições quanto para os seus clientes, como, por exemplo, crises patrimoniais e de liquidez.

Detectada essa situação anormal entra em ação a fiscalização direta realizada pelas equipes de inspetores do BACEN.

As atividades de supervisão são desempenhadas pela Diretoria de Fiscalização (DIFIS), com os respectivos departamentos, e pela Diretoria de Normas e Organização do Sistema Financeiro (DINOR) e departamentos.

Diante da impossibilidade das instituições financeiras impetrarem concordata, surge diante situações de risco, como crises patrimoniais, de liquidez e infrações a normas legais que disciplinam suas atividades, a necessidade da decretação de um regime especial a ser escolhido dentre os existentes, levando-se em consideração o grau de risco apresentado.

Nosso ordenamento jurídico prevê três espécies de regimes especiais ou saneadores, a saber: intervenção, liquidação extrajudicial e regime de administração especial temporária (RAET). Os dois primeiros estão previstos e disciplinados na Lei no 6.024 , de 13 de março de $1974^{12}$, enquanto o RAET foi instituído e disciplinado pelo Decreto-lei no 2.321, de 25 de fevereiro de $1987^{13}$, conhecido como “Lei do Colarinho Branco".

Ressalte-se que os regimes especiais não alcançam as instituições públicas federais, uma vez que, já estão sob direção direta dos órgãos supervisores.

11 SADDI, Jairo (Org.). Intervenção e Liquidação Extrajudicial no Sistema Financeiro Nacional. São Paulo: Textonovo, 1999. p. 76.

12 BRASIL. Lei no 6.024, de 13 de março de 1974. Dispõe sobre a intervenção e a liquidação extrajudicial de instituições financeiras, e dá outras providências. Diário Oficial, Brasília, DF, p. 002865, 14 mar. 1974.

13 BRASIL. Decreto-Lei no 2.321, de 25 de fevereiro de 1987. Institui, em defesa das finanças públicas, regime de administração especial temporária, nas instituições financeiras e públicas não federais, e dá outras providências. Diário Oficial, Brasília, DF, p. 002797, 26 fev. 1987. 
A intervenção pode ser entendida como uma medida de natureza cautelar, com o objetivo de evitar a liquidação extrajudicial ou mesmo a falência de uma instituição financeira, protegendo a poupança popular e primando pela higidez do sistema financeiro.

As seguintes hipóteses ensejam a sua decretação: a) situação de prejuízo resultante de má gestão sujeitando os credores a risco; b) verificação de reiteradas infrações à dispositivos da legislação bancária não regularizadas após determinação do BACEN; c) configuração das hipóteses previstas nos artigos 10 e 20 da Lei de Falências ${ }^{14}$ (impontualidade e presunção de insolvência), e desde que haja a possibilidade de se evitar a liquidação extrajudicial.

Embora se diga que o objetivo maior da intervenção é o de preservar a instituição, algumas dificuldades surgem contrariamente a essa afirmação, pois a partir do momento em que é decretada, várias conseqüências adversas são experimentadas pelo público, como, por exemplo, a inexigibilidade dos depósitos existentes à época da decretação.

O RAET vem a ser o regime especial mais adequado para recuperar as instituições financeiras, e isso porque, de acordo com a primeira parte do artigo $2^{\circ}$ do diploma legal instituidor, a sua decretação não afetará o curso regular dos negócios da entidade nem seu normal funcionamento.

Ensejam a sua decretação: a) prática de operações contrárias às diretrizes de política econômica ou financeira traçadas em lei federal de forma reiterada; b) existência de passivo a descoberto; c) descumprimento das normas referentes à conta de reservas bancárias mantida pelo BACEN; d) gestão temerária ou fraudulenta de seus administradores; d) ocorrência de qualquer das situações que ensejam a decretação de intervenção.

A liquidação extrajudicial, por sua vez, consiste em medida administrativa drástica cujo objetivo é o saneamento do sistema financeiro, promovendo a extinção e eliminação da empresa, conduzindo aos mesmos resultados do procedimento concursal judicial que é a falência.

Ensejam sua decretação: a) ocorrências que comprometam a situação econômica ou financeira da instituição, especialmente quando deixar de satisfazer com pontualidade seus compromissos, ou quando se caracterizar qualquer dos motivos que autorizem a

14 BRASIL. Decreto-Lei no 7.661, de 21 de junho de 1945. Lei de Falências. Diário Oficial, Rio de Janeiro, RJ, p. 000001, 31 jul. 1945. 
declaração de falência; b) violação grave por parte da administração das normas legais e estatutárias que disciplinam a atividade da instituição, bem como as determinações do CMN ou do BACEN, no uso de suas atribuições legais; c) quando a instituição sofrer prejuízo que sujeite a risco anormal seus credores quirografários; d) quando, cassada a autorização para funcionar, a instituição não iniciar, nos 90 (noventa) dias seguintes, sua liquidação ordinária, ou quando, iniciada esta, verificar o BACEN que a morosidade de sua administração possa acarretar prejuízos para os credores.

Com a decretação da liquidação extrajudicial, além da intervenção e do RAET (por força da Lei $\mathrm{n}$ - 9.447, de 14 de março de 1997), ou mesmo decretada a falência da instituição financeira, deve o BACEN instaurar o inquérito para apuração das causas e responsabilidades, com prazo de cento e vinte dias para a conclusão, permitida prorrogação por igual período em havendo necessidade absoluta.

Está regulado nos artigos 41 a 45 da Lei no 6.024, de 13 de março de 1974, sendo permitido e atribuído ao BACEN poderes para o exame de contabilidade, arquivos, documentos, dos autos da falência, tomada de depoimentos (inclusive com auxílio policial), solicitação de informações a qualquer autoridade ou repartição pública, e ainda o exame da contabilidade, arquivos e contas junto a outras instituições financeiras de terceiros com quem a instituição teve ou tem negócios, bem como de ex-administradores.

Para a configuração da responsabilidade objetiva do Estado, isto é, independentemente de dolo ou culpa, basta a relação causal entre o comportamento e o evento, abarcando as seguintes situações: a) danos ocasionados por ação, conduta positiva do Estado; b) danos advindos do risco a que terceiros são expostos em decorrência de uma situação propiciatória de dano criada pelo próprio órgão estatal.

A responsabilidade subjetiva é aquela em que a obrigação de indenizar surge em razão de uma conduta ilícita, de um procedimento contrário ao Direito, doloso ou culposo. Ocorre a culpa do serviço quando esse não funciona, funciona mal ou funciona tardiamente, relacionando-se, assim, com a conduta omissiva, ou seja, quando o dano foi possível em decorrência de uma omissão do Poder Público.

15 MELLO, Celso Antônio Bandeira de. Curso de Direito Administrativo. 14. ed. São Paulo: Malheiros, 2002. 
Nessas situações o Estado não agiu ou agiu mal, não sendo, por conseguinte, o autor do dano, só cabendo falar em sua responsabilidade quando tinha o dever legal de impedir a ocorrência do evento lesivo.

Em descumprindo um dever legal que atua como condição para a ocorrência do dano, o órgão estatal acaba por praticar um ilícito, seja por culpa, nas suas diversas modalidades (imprudência, negligência, imperícia) ou por dolo.

As autarquias, como o BACEN, respondem pelos seus atos gravosos à esfera juridicamente protegida de outrem até a exaustão de seus recursos, surgindo posteriormente a responsabilidade subsidiária do Estado, pois foi quem as criou e outorgou poderes que acabaram por ocasionar ou permitir a lesão jurídica. Responsabilidade direta das autarquias e subsidiária do Estado, observado o artigo 100 e parágrafos do texto constitucional.

Os correntistas, investidores, depositantes, enfim, clientes de instituições financeiras, ao confiarem a estas a propriedade de valores até então seus, realizam a operação com a certeza e segurança de os reaver, e isto face à atuação supervisora do BACEN com vistas a detectar qualquer tipo de anormalidade, contando com todo o instrumental apresentado.

Nas palavras de Francisco J. de Siqueira ${ }^{16}$ :

Nesse contexto, pois, a função de saneamento do mercado, a cargo do Banco Central, não se restringe ao afastamento das instituições bancárias, por dificuldades verificadas no seu ambiente operacional. Tem o governo a responsabilidade também de atuar preventivamente, evitando que o mal ocorra.

Evitar que o mal ocorra compreende ação perante determinada situação problemática, porém, passível de ser revertida, propiciando a recuperação, ou ainda, atuação diante de situações sem possibilidade de recuperação para restringir a ocorrência a danos de pouca monta, capazes de serem cobertos pelo patrimônio da instituição e/ou pelo FGC, e mesmo que sem essa possibilidade de cobertura, danos de menor repercussão econômica, ou seja, evitando que os prejuízos venham a se avolumar.

Nesse ínterim, crises de liquidez constantes com a necessidade da instituição recorrer repetidas vezes ao depósito interbancário (empréstimo entre instituições bancárias)

16 SADDI, op. cit., p. 89. 
ou à janela de redesconto oferecida pelo BACEN (avaliadas as garantias oferecidas), acompanhada de endividamento perene e crescente, sem a decretação do regime especial cabível, dada a particularidade da situação.

Para Eduardo Luís Lundberg ${ }^{17}$ :

Evidentemente, um órgão de supervisão ineficiente sempre pode ser responsabilizado por tornar mais freqüentes os casos de insolvência e aumentar a extensão dos prejuízos causados, não intervindo tempestivamente quando detectados os primeiros sinais de problemas.

E continua a respeito de algumas dentre as possíveis "limitações" à atuação, o que acaba por expor os clientes a prejuízos ${ }^{18}$ :

[...] A primeira limitação é de ordem política [...] bancos formam fortes laços econômicos junto às regiões e atividades em que prestam serviços e, na presença do risco de serem fechados, naturalmente fazem pressão política pela defesa dessas instituições. Um órgão supervisor pode simplesmente não ter o necessário respaldo político para levar a cabo a liquidação. Em certa medida, inclui-se nessa situação a interpretação de que a insolvência não está suficientemente caracterizada para justificar a intervenção.

[...]

Outra razão invocada para o não fechamento de bancos insolventes é a incompetência, desaparelhamento e até o 'moral hazard' do órgão supervisor. Um órgão de supervisão, por incompetência de seus quadros ou falta de uma estrutura adequada de fiscalização, pode não detectar situações de insolvência da instituições sob sua supervisão.

[...]

Por vezes, também existem limitações orçamentárias para levar a cabo as intervenções e liquidações. Tais operações podem ser custosas a curto prazo, pois significam o reconhecimento tempestivo de perdas junto a depositantes, o não recebimento de tributos recolhidos com base nos lucros fictícios envolvidos, etc.

Não se pode olvidar que em alguns casos a omissão pode advir inclusive de hipóteses veementes de dolo, seja por conta de favores pessoais, oferecimento de valores, dentre muitos outros, em síntese corrupção.

Compartilhando da mesma opinião Ivan Paulo Machado, embora em artigo que, ao contrário do presente trabalho, entende pela responsabilidade objetiva do BACEN em caso de omissão na função de fiscalização ${ }^{19}$ :

17 SADDI, op. cit., p. 46.

18 SADDI, op. cit., p. 47 seq.

19 MACHADO, Ivan Paulo. Da Responsabilidade Civil Objetiva do Banco Central na Intervenção e Liquidação Extrajudicial das Instituições Financeiras. São Paulo: RT, v. 790, ago. 2001, p. 171-179. 


\begin{abstract}
A displicência e lentidão dos representantes do Banco Central, uma vez constatada a eventual quebra ou insolvência bancária, deve ser punida, pois, no mais das vezes, tal atitude negligente gera enormes prejuízos aos correntistas, tendo em vista que, se o mesmo tivesse agido consoante determina a Constituição Federal, fiscalizando o Banco que apresenta problemas em suas contas, talvez o mesmo não quebrasse, e não lesaria os seus clientes e muitos outros, decorrente da bola de neve que se cria, levando-os à bancarrota e obrigando-os a se tornarem inadimplentes, perdendo todo seu dinheiro.

A intervenção tardia demonstra, para bem da verdade, que o serviço de vigilância e fiscalização a cargo do Banco Central não funcionou, quando deveria legalmente funcionar, quer por ação ou inação, descumprindo os seus deveres legais. O Banco Central, conquanto houvesse tomado conhecimento ou não das irregularidades, fazse cego, esquivando-se de tomar uma atitude, sendo pois, desta forma, inerte, não adotando as medidas e providências que lhe competem constitucionalmente, para adefesa do público. De conseguinte se o serviço funcionou mal, ensejando as lesões a terceiros, a reparação de tal lesão há de ser satisfeita pelo Bacen.
\end{abstract}

Ainda Nelson Abrão, embora no contexto de sua obra mencione a imputação de responsabilidade objetiva ${ }^{20}$ :

Entrementes, os técnicos do Banco Central têm demonstrado letargia e falta de pulso na verificação do problema, resultando em uma tomada de ordem que instabiliza o mercado ou privilegia determinada entidade.

Quando age contemplando a operação prejudicial, ou quando se omite, na realidade deve o Banco Central responder pelos prejuízos causados, dentro da relação causa e efeito, em face do dano que permite infundir aos investidores e poupadores.

A decretação tardia de medidas como a intervenção e, melhor ainda, o RAET, ou mesmo a falta destas quando era necessário, frente a uma decretação posterior e direta da liquidação extrajudicial, em alguns casos acompanhada da evolução para a falência, são situações que demandam responsabilidade pelos prejuízos causados pela falta de cumprimento do dever legal, especialmente por não se agir preventivamente, evitando que o mal ocorresse ou limitando a extensão de seus prejuízos.

Até mesmo a não decretação da liquidação extrajudicial quando oportuna, para posteriormente ser decretada, possibilitando, frise-se, a expansão do dano ao direito de crédito.

Eis a posição de Luiz Tzirulnik em idêntico sentido ${ }^{21}$ :

20 ABRÃO, Nelson. Direito Bancário. 5. ed. São Paulo: Saraiva, 1999. p. 247.

21 TZIRULNIK, op. cit., p. 33. 
Tem-se, portanto, que a função supervisora e controladora do Banco Central, no sentido de manter saudável o mercado financeiro, não há de se restringir ao afastamento das instituições financeiras por dificuldades manifestas em suas operações. É também, e, sobretudo, responsabilidade do governo atuar preventivamente, evitando sequer que o mal se expresse.

Verificada a omissão diante de uma obrigação legal, acompanhada da culpa ou do dolo, caracterizada está uma violação a certo dever jurídico, e, portanto, um ato ilícito, permitindo-se a ocorrência do resultado danoso.

Muito embora a omissão não dê causa a nenhum resultado, é a condição que permitiu a ocorrência do evento danoso à esfera juridicamente protegida de outrem, ensejando a responsabilização.

Em conformidade com o entendimento até então exposto, Celso Antônio Bandeira de Mello, em parecer sobre responsabilidade pública por danos causados por instituições financeiras ${ }^{22}$ :

Assim, uma simples consulta às Leis 4.595 e 4.728 , dos quais salientamos alguns dispositivos, permite verificar, de imediato, que:

a) é dever do Banco Central - pois as competências como se sabe são 'deverespoderes', irrenunciáveis, inderrogáveis pela vontade das partes e irrecusáveis por quem as detêm - 'garantir o funcionamento normal e regular das instituições financeiras', para assegurar a lisura de suas operações e 'proteger os investidores';

b) o Banco Central dispõe de 'amplíssimos poderes de ingerência e controle e fiscalização' no setor, bem como de aplicar sanções, o que o instrumenta eficazmente para bem atender às finalidades em nome das quais the foram irrogadas suas competências, circunstância esta que the permite prevenir ou abortar comportamentos lesivos de instituições financeiras ou - quando menos, nos casos de comportamentos censuráveis mais esquivos à identificação - de evitar que eventuais ações danosas se expandam.

É certo, pois, que, se atuar com prudência, diligência e perícia normais, está habilitado a oferecer aos investidores aquilo que ditas leis Ihe impõem que ofereça: proteção, resguardo, de molde a evitar que sejam vítimas de ação fraudulenta, irresponsável, predatória no mercado, lesiva ao patrimônio de aplicadores.

[...]

É certo, portanto, e para além de qualquer dúvida ou entredúvida que a autarquia federal Banco Central incorreu em manifesta 'falta de serviço', quer por inação faltando a seus deveres legais - quer por ação, descumprindo, também nisto, seus deveres legais.

Isto posto e ante todo o considerado, à indagação respondo: O Banco Central, em face dos princípios acolhidos pela legislação brasileira e pela jurisprudência do País, é 'responsável e deve responder pelos danos sofridos pelos Consulentes' em decorrência da insolvência do Grupo Coroa, já que incorreu em manifesta 'falta de serviço' e ensejou a lesão patrimonial que os agravou.

22 MELLO, Celso Antônio Bandeira de. Responsabilidade Pública por Danos Causados por Instituições Financeiras. São Paulo: RDP-91. p. 243-252. 
Verifica-se incontestavelmente a possibilidade da responsabilização do BACEN por faute du service na função fiscalizadora, sobretudo preventiva, que exerce perante determinadas instituições que compõem o Sistema Financeiro Nacional e, portanto, como visto, aplicação da teoria da responsabilidade subjetiva.

Acaso a responsabilização fosse admitida com base na teoria objetiva, sérias conseqüências negativas ocorreriam ao Sistema Financeiro Nacional, pois as instituições que o compõe, diante da responsabilidade objetiva do BACEN em caso de comportamentos omissivos na fiscalização, passariam a operar com graus de remuneração cada vez maiores, sem a devida prudência, e, ainda sim, os investidores não teriam receio de realizar investimentos arriscados, a especulação estaria a solta, entre outros exemplos, já que o mercado visualizaria sempre como retaguarda a responsabilidade direta do BACEN e subsidiária do Estado, independentemente de culpa ou dolo, de forma que, o risco inerente à atividade econômico financeira restaria excluído.

A responsabilidade objetiva poderia vir a recair sobre comportamentos positivos do BACEN, como a decretação de regime especial sem a configuração dos requisitos essenciais para tanto, ocasionando prejuízos.

A omissão é condição que influi na linha causal, pertinente ao nexo de causalidade, como bem observa Sérgio Cavalieri Filho apud Ivan Paulo Machado ${ }^{23}$ :

Examinada a omissão pelo aspecto normativo, de que o Direito nos impõe, muitas vezes, o dever de agir, casos em que, nos omitindo, além de violar dever jurídico, deixamos de impedir a ocorrência de um resultado. Dessa forma, embora a omissão não dê causa a nenhum resultado, não desencadeie qualquer nexo causal, pode ser causa para não impedir o resultado.

Ora, não impedir significa permitir que a causa opere. O omitente, portanto, coopera na realização do evento, com uma condição negativa: ou deixando de se movimentar, ou não impedindo que o resultado se concretizasse. Responde por esse resultado não porque o causou com omissão, mas porque não impediu, realizando a conduta a que estava obrigado.

Conclui-se, do exposto, que a omissão adquire relevância causal porque a norma Ihe empresta esse sopro vital, impondo ao sujeito um determinado comportamento.

23 FILHO, Sérgio Cavalieri apud MACHADO, Ivan Paulo. Da Responsabilidade Civil Objetiva do Banco Central na Intervenção e Liquidação Extrajudicial das Instituições Financeiras. São Paulo: RT, v. 790, ago. 2001, p. 171179. 
A omissão adquire relevância na medida em que representa condição para que o resultado negativo venha a ocorrer.

Deve ser admitida a inversão do ônus da prova, face à presunção da culpa, até porque o evento a que se estava obrigado a fiscalizar e evitar, preventivamente, devido às conseqüências negativas que representa para a poupança popular e para a higidez do mercado, acabou por ocorrer, sob pena de se recriar a irresponsabilidade estatal, já que os administrados não tem todo o conhecimento pertinente às estruturas e poderes dos órgãos estatais.

Bem por isso, importantes todas as informações colhidas no inquérito administrativo instaurado por força da decretação dos regimes especiais, frise-se aqui, da liquidação extrajudicial, o qual ao menos poderá vir a fornecer indícios da saúde financeira da instituição ao longo dos anos e os acontecimentos verificados.

Quando o serviço público não funcionou, funcionou mal ou funcionou tardiamente, por culpa anônima e/ou dolo, violando o direito de crédito dos credores, imperativa a indenização por parte do órgão estatal responsável pela supervisão, compreendida a atividade de regulação e principalmente a função de fiscalização, possível do ponto de vista processual por meio de ação de indenização a ser proposta perante a Justiça Federal.

\section{Conclusão}

A supervisão exercida pelo BACEN junto ao Sistema Financeiro Nacional, atuando como agente regulador/normativo e fiscalizador, é forma de intervenção estatal no domínio econômico, baseada no interesse público.

Primar pela higidez do mercado e proteção dos clientes das instituições envolvidas, com vistas ao desenvolvimento econômico e social, é seu dever legal.

Para o exercício da função de fiscalização o BACEN conta com instrumental vasto, Diretorias e Departamentos especializados, cujo objetivo é atuar prontamente.

A omissão a dever legal consiste em condição que permite a ocorrência de danos, ensejando a responsabilização, observada a teoria subjetiva.

Há de ser admitida uma presunção de culpa, pois o evento que se busca evitar veio a ocorrer, sob pena de se inviabilizar a responsabilização, considerada a desigualdade de condições verificada entre a Administração e o particular. 
O serviço público não funcionou, funcionou mal ou funcionou tardiamente, por culpa anônima e/ou dolo.

Violado o direito de crédito dos credores, imperativa a indenização por parte do órgão estatal para reparar os danos ocorridos.

\section{Referências}

ABRÃO, Nelson. Direito Bancário. 5. ed. São Paulo: Saraiva, 1999.

BONAVIDES, Paulo. Do Estado Liberal ao Estado Social. 7. ed. São Paulo: Malheiros, 2004.

MACHADO, Ivan Paulo. Da Responsabilidade Civil Objetiva do Banco Central na Intervenção e Liquidação Extrajudicial das Instituições Financeiras. Revista dos Tribunais, São Paulo, v. 790, p. 171-179, ago. 2001.

MELLO, Celso Antônio Bandeira de. Curso de Direito Administrativo. 14. ed. São Paulo: Malheiros, 2002.

Responsabilidade Pública por Danos Causados por Instituições Financeiras. Revista de Direito Público, São Paulo, n. 91, p. 243-252.

SADDI, Jairo (Org.). Intervenção e Liquidação Extrajudicial no Sistema Financeiro Nacional. São Paulo: Textonovo, 1999.

TZIRULNIK, Luiz. Intervenção e Liquidação Extrajudicial das Instituições Financeiras. 2. ed. São Paulo: RT, 2000. 
